\title{
Pressure-Wave Propagation in Magnetorheological Fluid
}

\author{
by
}

\author{
Kohei Tateyama*, Yuya Mitani** and Keiko Watanabe*
}

Magnetorheological (MR) fluids are categorized as smart fluids, which are made of small iron particles suspended in carrier fluids such as silicone oil. The presence of a magnetic field will instantaneously increase the viscosity of the MR fluid, which is known as the MR effect. To expand the practical application of the MR fluid, it is very useful to study the pressure wave propagation under high-loading conditions in detail. Therefore, in this study, the behavior of the pressure wave propagating in MR fluid that was generated by the collision between an ultra-high speed projectile and MR fluid was investigated. The impact test was carried out using a vertical gas gun. Three underwater impact sensors were used to measure the pressure wave, and the history of pressure at each point was acquired. From the experimental result, it was found that the compressibility of MR fluid affected the magnitude of peak pressure generated by the entry of an ultra-high speed projectile into the MR fluid. Furthermore, it was confirmed that the yield shear stress and the increase in shear stress due to the magnetic field greatly affect the damping of the impact-induced pressure.

\section{Key words:}

Magnetorheological fluids, Pressure wave, Impact, Magnetic field

\section{1 緒言}

磁気粘性 (Magnetorheological) 流体（以下 MR 流体と記 す.) は, 鉄粉（直径数マイクロメートルの強磁性粒子), ベース溶液（炭化水素油やシリコーンオイル）および粒子 の分散性を向上させるための界面活性剤を混合して作製 される機能性流体である. MR 流体は, 無磁場下では一般 的な懸濁液体でありニュートン流体として振る舞う。し かし，外部から磁場を印加すると可逆的に流体内の鉄粉 粒子がクラスタと呼ばれる鎖状構造を形成し, 数十キロ パスカル程度の降伏せん断応力を持つビンガム流体に流 動特性が変化する。1),2)つまり, 見かけ粘度が急激に増加 し, 半固体状に性質が変化するといった特徴を持つ.この ような可逆的な特性は MR 効果と呼ばれており, 可逆的 かつ高速（10２0 ミリ秒）な現象である. ${ }^{3), 4)} \mathrm{MR}$ 効果は 印加する磁場によって幅広い制御が可能であることから 自動車のブレーキ5)やダンパー，6),7) 動力伝達アクチュエ 一タ 8) 等に既に応用されている. また，その固体でも流 体でもない独特な感触を制御することで利用者に力, 振 動，動きなど皮膚感覚を与えるハプティクスデバイス 9) としての利用も検討されており, MR 流体活用の場は今後 ますます拡大すると考えられる.

MR 流体はその現象が発見されて以来, 様々な研究が行 われてきた. MR 流体の降伏せん断応力と粒子濃度の関係 10), 11) や粒子濃度と内部のクラスタ構造が音速に及ぼす影 響 12) について等, 粒子濃度が MR 効果に大きく影響を及 ぼすことがわかっている，このとき，MR 流体に印加する
磁場を増加させると MR 効果が飽和することも報告され ている。13)また，磁場印加角度によって異方性が生じる ことも明らかにされており, 主に超音波伝ぱ特性の観点 から評価が行われている. $\left.{ }^{14)} \sim 16\right)$ 力学的特性については, 準静的圧縮試験結果より, 応力ーひずみ関係は 3 つの領 域 (弾性領域, プラトー領域, およびひずみの増加に伴い 応力が急激に増加する領域）に分類できることが示され ている、17) さらに MR 流体の内部構造に関しては, 球形 とフレーク形状の 2 種類の粒子を使用しクラスタの内部 に小さい粒子を内包させることで MR 効果を向上させた 報告 ${ }^{18)}$ など，粒子径や形状が MR 効果に及ぼす影響につ いても調査されている。しかし, 衝撃吸収システムとして 利用する際に必要となる高速な応答に関寸る研究につい ては報告が少なく, 各アプリケーションに対して個別に 実施，検討されているのみである.

そこで本研究では, 高速で飛翔する飛翔体が MR 流体 に突入した際に生じる衝突誘起圧力波を利用し, MR 流体 中を伝ぱする圧力波の挙動について調査することを目的 とした. 本報告では, MR 効果による圧力波の減衰を把握 するため, 無磁場下および磁場下で異なる粒子濃度の MR 流体に対して飛翔体高速衝突実験および粘度測定を行っ た.この際, 磁場印可は試験前に行っており, 磁場の変化 に伴う流動特性変化については考慮していない。これら の実験から, MR 流体の粒子濃度や磁場下における流動特 性変化が衝突誘起圧力波の減衰に与える影響を調査した.

$\dagger$ 原稿受理 令和3年4月19日 Received Apr. 19, 2021 @2021 The Society of Materials Science, Japan

* 正会員 立命館大学 理工学部機械工学科 $\bar{T} 525-8577$ 草津市野路東

Department of Mechanical Engineering, Ritsumeikan University, Noji-higashi, Kusatsu, 525-8577.

** 立命館大学 大学院理工学研究科 $7525-8577$ 草津市野路東

Graduate School of Science and Engineering, Ritsumeikan University, Noji-higashi, Kusatsu, 525-8577. 


\section{2 磁気粘性流体}

本研究で使用するMR流体は, 磁性体粒子, 分散媒およ び添加剤で構成されている。磁性体粒子には粒径約 $2 \mu \mathrm{m}$ のカルボニル鉄粉（Jiangsu Tianyi Ultra-fine Metal Powder 社製, YX5/5S), 分散媒には動粘度約 $1 \times 10^{-4} \mathrm{~m}^{2} / \mathrm{s}$ のシリコ ーンオイル（信越シリコーン社製，KF96-100CS），添加 剂には親油性界面活性剂としてオレイン酸（ナカライテ スク社製， cis-9-Octadecenoic Acid）をそれぞれ使用した。 本研究では, 磁気粘性流体の流動特性に及ぼす粒子濃度 の影響について検討するため, Table 1に示す体積分率に おいて 2 種類のMR流体を作製した。以下，カルボニル鉄 粉の体積分率が $15 \mathrm{vol} \%$ の試験体を $15 \mathrm{vol} \% \mathrm{MR}$ 流体，30 vol\%の試験体を30 vol\% MR流体と示す.

Table 1 MR fluid composition of volume fraction.

\begin{tabular}{ccc}
\hline MR fluid & 15 vol\% & 30 vol\% \\
\hline $\begin{array}{c}\text { Silicone oil } \\
{[\text { vol\%] } \%}\end{array}$ & 83.3 & 66.5 \\
$\begin{array}{c}\text { Carbonyl iron powder } \\
{[\text { vol\%] }}\end{array}$ & 15.0 & 30.0 \\
$\begin{array}{c}\text { Oleic acid } \\
{[\text { vol\%] } \%}\end{array}$ & 1.7 & 3.5 \\
\hline
\end{tabular}

\section{3 高速衝突実験}

\section{$3 \cdot 1$ 飛翔体}

本研究で使用した飛翔体は円柱形であり，インパクタ (黄銅) とサボ (高密度ポリエチレン) で構成されている. 飛翔体の形状および寸法を Fig. 1 に示す。直径 $15 \mathrm{~mm}$, 高 さ $26 \mathrm{~mm}$ であり，質量は約 $15-16 \mathrm{~g}$ である.

\section{$3 \cdot 2$ 飛翔体加速装置}

MR 流体は液体であるため, 高速衝突実験において縦向 きに設置する必要がある, そこで本研究では, 飛翔体加速 装置として縦型ガス銃 (以下，ガス銃）を用いた。ガス銃 を含めた実験セットアップの概略図を Fig. 2 に示す. ガス 銃は駆動高圧室, 加速管（長さ： $2 \mathrm{~m}$, 内径 : $15 \mathrm{~mm}$ ), 速 度測定装置, 実験容器および試験室で構成されており, 飛 翔体は駆動高圧室の真下に装填する構造になっている. ターゲットである MR 流体は，加速管直下に設置した実 験容器内に充填した。速度測定装置にはレーザーカット 方式を採用し，加速管の出口付近にレーザーと受光素子 を $20 \mathrm{~mm}$ 間隔で 3 セット設置した.

\section{$3 \cdot 3$ 実験容器}

MR 流体に対する飛翔体高速衝突実験では, 磁場を印加 するため実験容器には非磁性体を用いる必要がある。そ こで, 実験容器は材質にアルミニウム合金を用いた. 実験 容器の寸法は内径 $160 \mathrm{~mm}$, 高さ $300 \mathrm{~mm}$ の円筒形容器で ある。実験容器内部には，飛翔体が MR 流体に高速衝突 した際に生じる圧力波の圧力を測定するために水中衝撃 センサ（Dr. Müller Instruments 社製，Platte Needle Probe） を設置した. センサ設置の詳細を Fig. 3 に示す. センサは 液面から Y 軸負の方向に $30 \mathrm{~mm}$ 間隔, 衝突中心から $\mathrm{X}$ 軸 方向に $35 \mathrm{~mm}$ の位置に 3 本設置した. 本センサは, 圧力 $\phi 15$
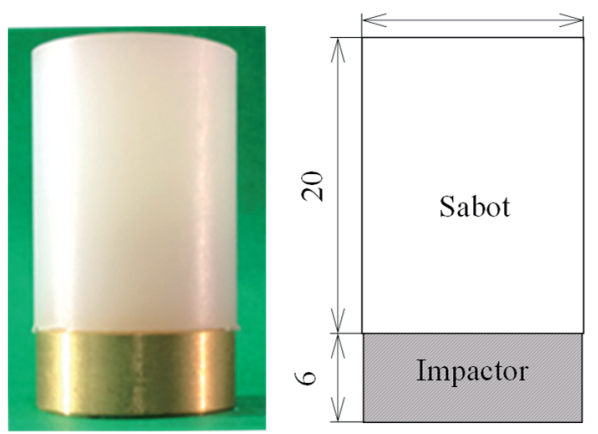

Unit : mm

Fig. 1 External view and dimensions of the projectile.

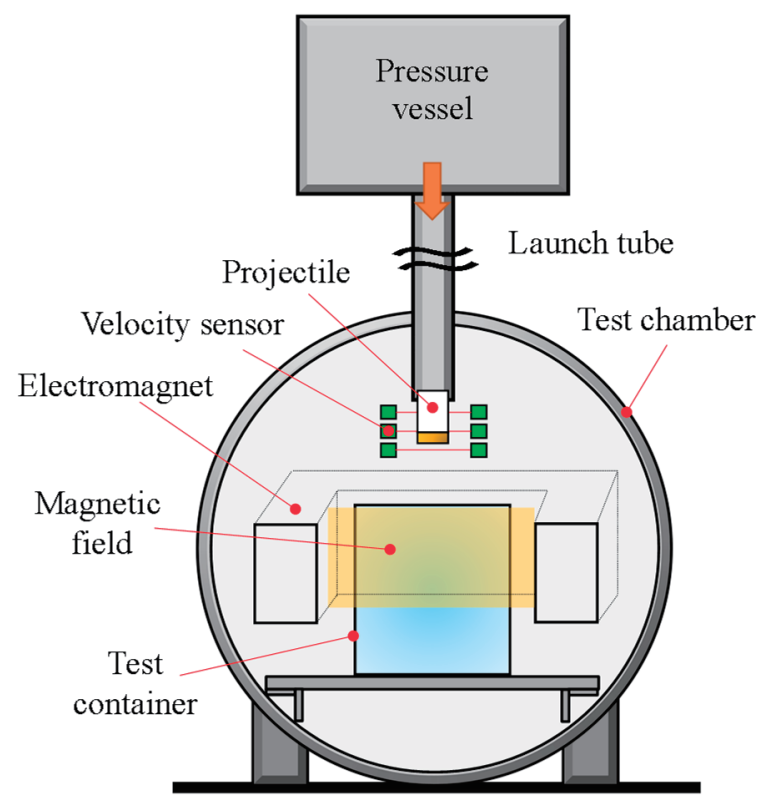

Fig. 2 Schematic view of the experimental setup.

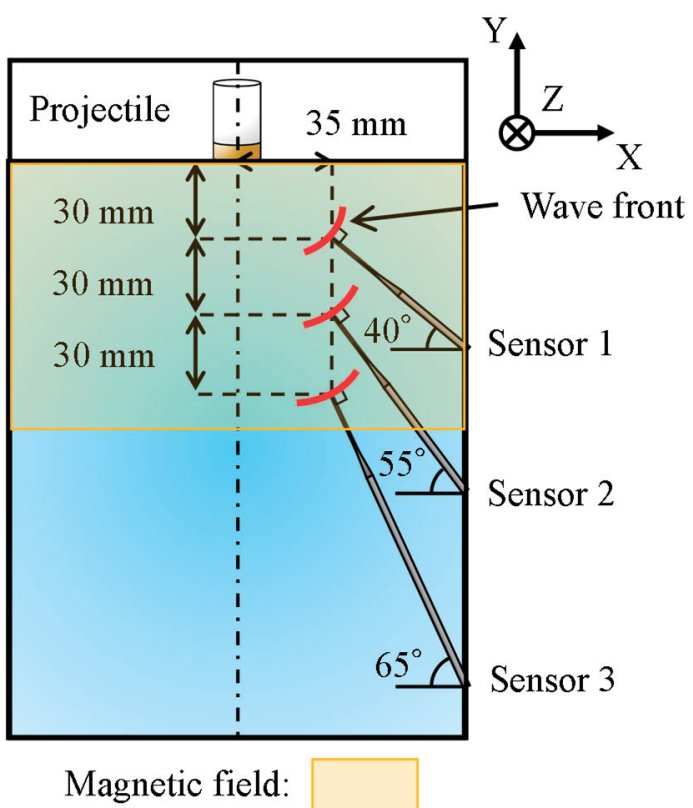

Fig. 3 Schematic view of the test container and sensor position. 
波に対して垂直に設置する必要があるため, 数值解析に より圧力波の伝ぱを再現し，それぞれのセンサ位置毎に 適切な角度を決定した。

MR 流体に対して磁場を印加するため, 電磁石を作製 し Fig. 2 に示すように実験容器に取り付け使用した。作 製した電磁石の概略図を Fig. 4 に示寸. 電磁石は電磁軟 鉄（SUY）と銅線で構成されており，コの字型の電磁軟 鉄に銅線を 3000 巻きした. この銅線に電流を流すこと により磁場が発生し，その磁場が電磁軟鉄内部で増幅さ れ平板間に均一な磁場が印加される. 本実験では, 約 95 $\mathrm{V}, 1.2 \mathrm{~A}$ の条件で電圧・電流を設定し, 平板間に約 10 $\mathrm{mT}$ の磁場を発生させた。磁場範囲は液面から深さ約 $100 \mathrm{~mm}$ までの領域であり, 磁束方向はZZ軸方向である.

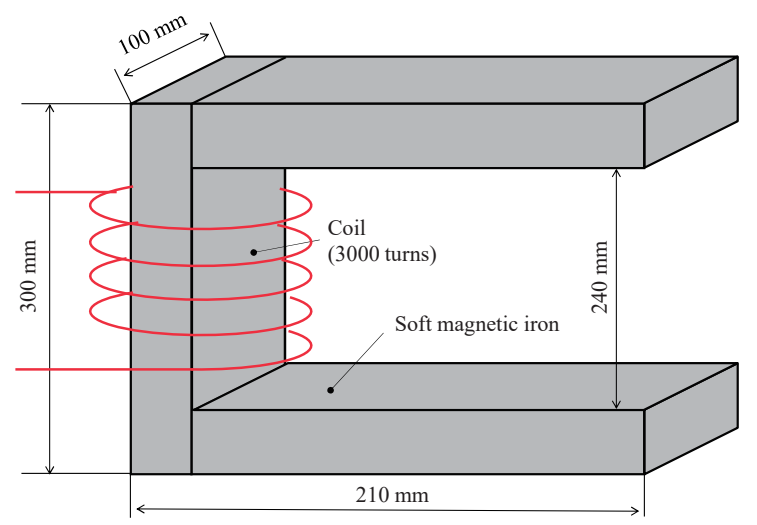

Fig. 4 External view of the electromagnet.

\section{$3 \cdot 4$ 実験条件}

15 vol\%および 30 vol\%の 2 種類の MR 流体に対して, 無磁場下（0 mT）および磁場下（10 mT）の 2 条件で高速 衝突実験を行った。飛翔体速度はすべての条件で目標速 度 $220 \mathrm{~m} / \mathrm{s}$ に対して誤差約 $2 \%$ 範囲内であった。

\section{4 実験結果および考察}

\section{$4 \cdot 1$ 衝突誘起圧力波の伝ぱ特性}

一例として無磁場下の $15 \mathrm{vol} \% \mathrm{MR}$ 流体に飛翔体が衝突 した際に水中衝撃センサが検知した波形を Fig. 5 に示寸. Fig. 5 の横軸 $0 \mu \mathrm{s}$ は飛翔体が液面に衝突した時刻を示す. 各センサでの波形の立ち上がりはすべて急峻なピークを 示し，ピーク圧力はセンサ 1 ，センサ 2 ， センサ 3 の順番 で減衰していることが確認できた。この傾向はすべての 実験において同様に確認された。 また, 各センサの圧力履 歴についてみると，圧力波頭がセンサを通過して第一の ピークを示したのち, 第二, 第三のピークが観察された. これは，センサと容器壁面との距離および MR 流体の音 速より，圧力波がセンサを通過したのちに容器壁面で反 射して再度センサに入射することで生じたと考えられる。

球面圧力波はセンサに衝突する角度によって計測され る圧力に差異が生じる. そのため, 各センサによって計測 した圧力には補正が必要である, Fig. 6 に圧力補正のため の概略図を示す. 圧力は Fig. 6 の青い点の位置に設置し た水中衝撃センサで計測している。しかし, 飛翔体衝突時

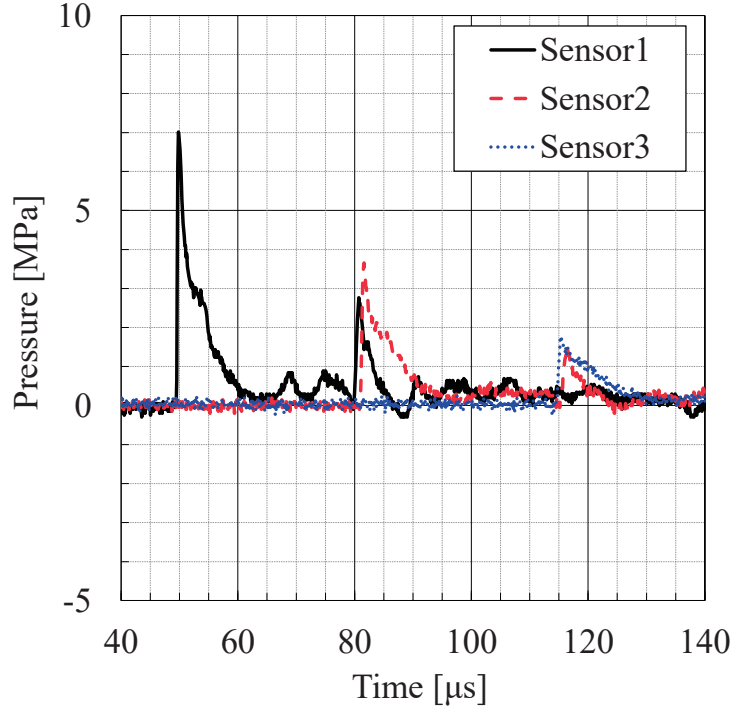

Fig. 5 Typical pressure signals in 15 vol\% MR fluid without magnetic field.

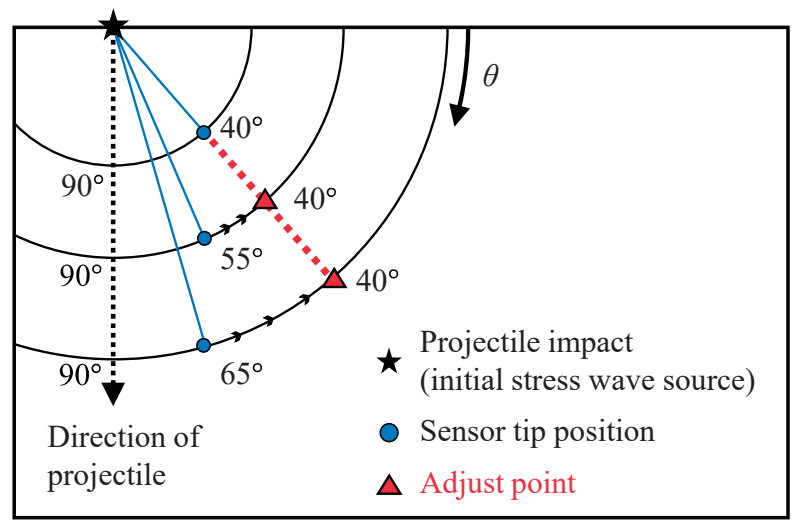

Fig. 6 Schematic diagram of adjustment of measurement point.

に伝ぱする球面圧力波の減衰を正確に調査するには，40。 で設置しているセンサを起点にし, その延長上 (赤色の破 線) で評価しなければならない. そこで, センサ 2 とセン サ3のピーク圧力を下記の式を用いて補正する.

$$
p=p_{90^{\circ}} \sin \left(\theta \pm 7^{\circ}\right)
$$

式(1)は Huang ${ }^{19)}$ らが円柱飛翔体を用いた実験から導いた 圧力波のピーク圧力の補正式である. $p$ は補正後の圧力, $\theta$ は衝突点と圧力計測点を結んだ線と液面のなす角度

(Fig. 6 参照), $p_{90^{\circ}}$ は $\theta=90^{\circ}$ (飛翔体進行方向) におけ る圧力波のピーク圧力である. また, 補正式の $\pm 7^{\circ}$ の值 は補正による誤差である.

ここで，飛翔体が衝突した瞬間から各センサに出力が 得られるまでの時間から各 MR 流体の音速を算出した。 この際, センサ 1-2 間およびセンサ 2-3 間でそれぞれ音速 を算出したところ, センサ 1-2 間で算出した值に比べてセ ンサ2-3 間で算出した值の方が約 $3 \%$ 高い值が算出される 傾向が得られた。これは, センサ 1-2 間において衝撃圧縮 に伴う密度変化が生じたことで音速が低く算出されたも 
Table. 2 Sound speed and compressibility of MR fluid.

\begin{tabular}{ccc}
\hline MR fluid & $\begin{array}{c}\text { Sound speed } \\
c[\mathrm{~m} / \mathrm{s}]\end{array}$ & $\begin{array}{c}\text { Compressibility } \\
\alpha\left[\mathrm{MPa}^{-1}\right]\end{array}$ \\
\hline 15 vol\% & 775 & $0.84 \times 10^{-3}$ \\
15 vol\%_mag & 812 & $0.76 \times 10^{-3}$ \\
30 vol\% & 721 & $0.64 \times 10^{-3}$ \\
30 vol\%_mag & 737 & $0.61 \times 10^{-3}$ \\
\hline
\end{tabular}

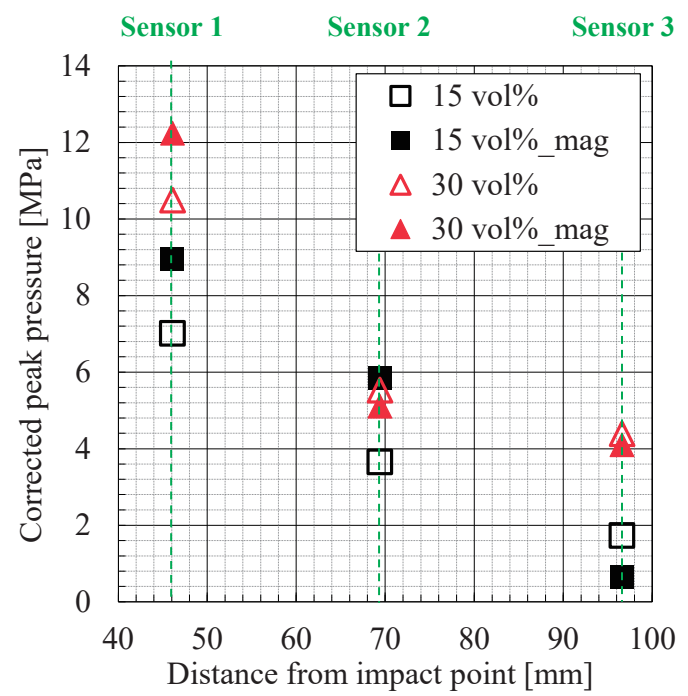

Fig. 7 Relationship between corrected peak pressure and distance from impact point.

のと考えられる. 本論文中では, MR 流体の音速はセンサ 1-2 間およびセンサ 2-3 間で算出した音速の平均值とした また, MR 流体中を伝ぱする圧力波の挙動について評価す るため, 体積弾性率の逆数である圧縮率 $\alpha$ を算出した. 音 速を $c$, 密度を $\rho$ とすると圧縮率 $\alpha$ は,

$$
\alpha=\frac{1}{c^{2} \rho}
$$

と表すことができる．実験から得られた MR 流体の音速 および式(2)より得られた圧縮率 $\alpha$ を Table 2 に示す. 以下, 磁場下で取得した結果は図および表中に mag と示す. 実 験から得た MR 流体の音速は, Wood の有効媒質理論 ${ }^{12)}$ の傾向に従い, 粒子濃度の増加に伴い低下した. また, MR 流体は磁場を印加することにより音速が上昇することが 確認された. これは MR 流体の内部構造の変化によって 生じたと考えられる.

圧力補正後の各条件のピーク圧力を示寸グラフを Fig. 7 に示す. センサ 1 におけるピーク圧力值に着目すると, MR 流体中を伝ぱする圧力波は圧縮率の低いものからピ 一ク圧力が高くなることがわかる.しかし，センサ 2 およ び 3 におけるピーク圧力值に着目すると, 波の伝ぱ距離 によってその減衰傾向が変わることが確認された。ここ で, 波の伝ぱ距離が圧力波の減衰に与える影響を調査す るため, 各 MR 流体で計測されたセンサ 1 の圧力をもと

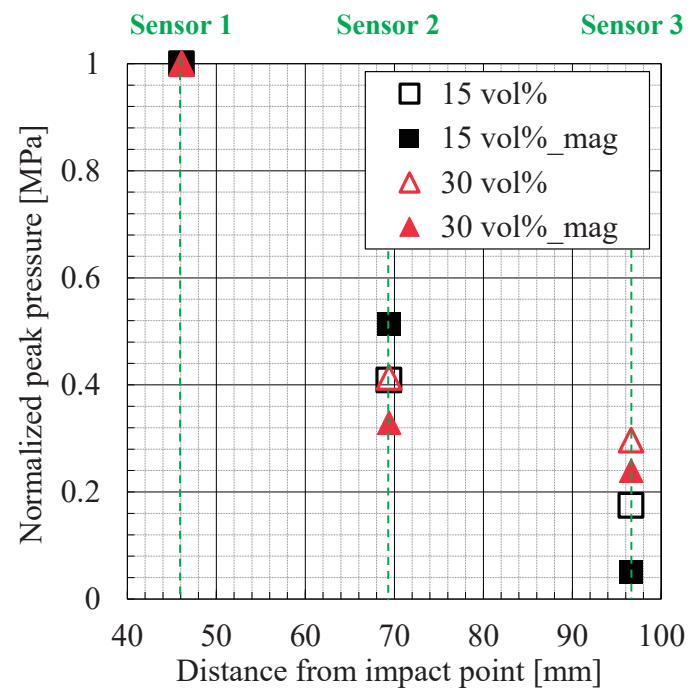

Fig. 8 Relationship between normalized peak pressure and distance from impact point.

に正規化をした結果を Fig. 8 に示す.センサ 3 において, 補正後の正規化したピーク圧力は無磁場下より磁場下の MR 流体の方が小さくなった。これは，MR 流体に磁場を 印加することで生じる MR 効果の影響によって衝突誘起 圧力波が減衰したためと考えられる. 一方, センサ 2 に着 目すると， $15 \mathrm{vol} \% \mathrm{MR}$ 流体ではセンサ 1 と同様に圧縮率 の低いものからピーク圧力值が高くなる傾向が得られた が，30 vol\%MR 流体ではセンサ 2 の時点でセンサ 1 にお ける傾向と逆の傾向が得られた. これは, 粒子濃度が変わ ることによって MR 効果に起因する減衰の傾向が変化し たためと考えられる.ここで, 衝突誘起圧力波の減衰に及 ぼす MR 効果の影響について詳しく検討するため MR 流 体の流動特性に注目し，無磁場下および磁場下で異なる 粒子濃度の MR 流体に対して流動特性評価を行った.

\section{$4 \cdot 2$ 流動特性の影響}

MR 流体の流動特性測定は回転粘度計（Brookfield 社製, DV2T）を使用し，磁場印加には永久磁石であるネオジム 磁石を用いて行った。磁場印加方向は回転粘度計の回転 軸方向に平行であり, MR 流体に印加される磁束密度は衝 突実験と同様に $10 \mathrm{mT}$ となるよう距離を調整した。15 vol\%MR 流体と $30 \mathrm{vol} \% \mathrm{MR}$ 流体に対して無磁場下および 磁場下の各条件で粘度およびせん断応力測定を行った。

流動特性測定により得た降伏せん断応力および粘度変 化を Fig. 9 および Fig. 10 に示す. 本論文で実施した流動 特性測定はせん断速度 $80 \mathrm{~s}^{-1}$ 以下における結果であり 3 章 で行った高速衝突実験における現象とは時間スケールが 厳密には異なる. そこで, せん断速度 $0 \mathrm{~s}^{-1}$ におけるせん 断応力である降伏せん断応力（流動を始めるのに必要な せん断応力）に特に着目して評価を行う。無磁場下の 15 vol\% MR 流体以外では, 降伏せん断応力を持つことが確 認された. 降伏せん断応力に着目すると, $15 \mathrm{vol} \% \mathrm{MR}$ 流 体では無磁場下において降伏せん断応力を持たず粘度も せん断速度による変化は無い（ニュートン流体として振 る舞う) が, 磁場下では降伏せん断応力を持つビンガム流 


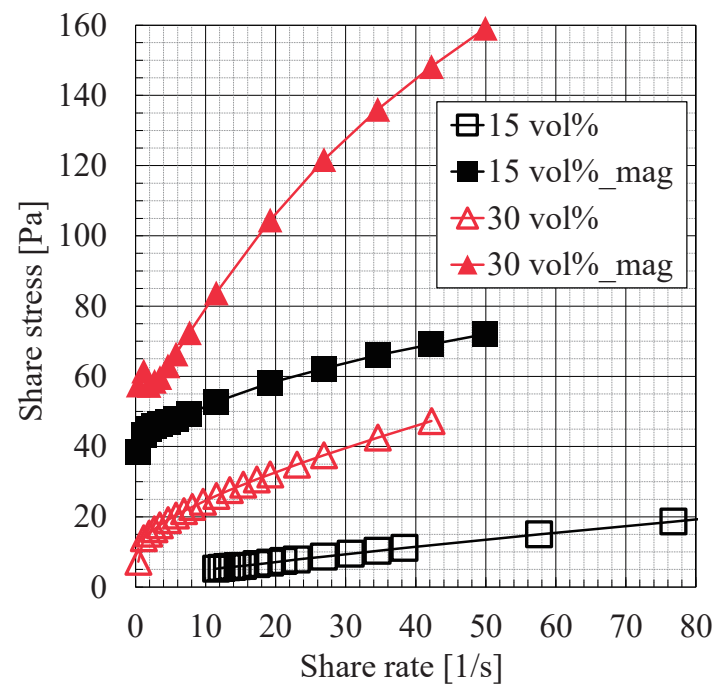

Fig. 9 Shear rate and shear stress of MR fluid.

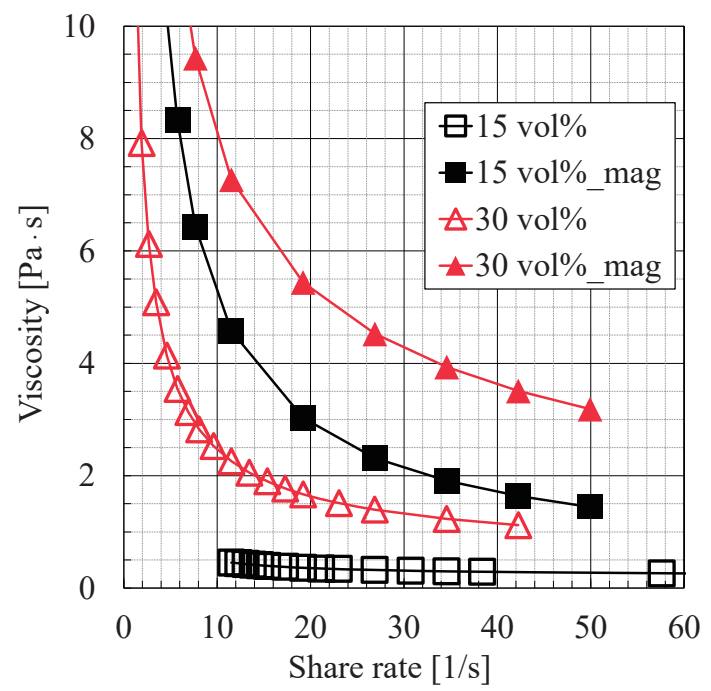

Fig. 10 Shear rate and viscosity of MR fluid.

体としての特性に変化することが確認された。この変化 は MR 効果によるものと考えられる。一方， $30 \mathrm{vol} \% \mathrm{MR}$ 流体では磁場条件に関わらず降伏せん断応力を持つこと がわかる。これは, 粒子濃度が増加することで無磁場下で も MR 流体中の粒子の摩擦がせん断抵抗として作用する ためだと考えられる．せん断応力に着目すると， $15 \mathrm{vol} \%$ MR 流体および $30 \mathrm{vol} \% \mathrm{MR}$ 流体ともに磁場下では無磁場 下と比較して大きい值を示すことがわかった，さらに，磁 場下では，せん断速度増加に伴うせん断応力の上昇は粒 子濃度に依存して大きくなった。 これは, 粒子濃度が増加 することで生成されるクラスタの数が増加し, クラスタ の断裂と結合に起因した流動抵抗が増加するためと考え らえる．粘度について見ると，無磁場下での 15 vol\% MR 流体以外でせん断速度の上昇につれて粘度が減少した。 これは，低せん断速度域では降伏せん断応力の影響を強 く受け見かけの粘度が上昇しているためである.また，降 伏せん断応力による影響が小さくなり粘度が一定值に近 づくせん断速度 $40 \mathrm{~s}^{-1}$ 以上に注目した。磁場下での各 MR 流体の粘度は無磁場下の各 MR 流体粘度よりが絶対值が
大きくなった. これは, クラスタが流動抵抗となり MR 流 体の粘度を上昇させていることを示していると考えられ る. 本論文で扱う MR 流体はビンガム流体およびニュー トン流体として振る舞うことから, 上記傾向はせん断速 度が上昇しても同様に生起すると推察される。

高速衝突実験の結果から, 飛翔体衝突時には衝突点付 近においてピーク圧力は圧縮率に依存し，センサ 1 では 圧縮率の低いものからピーク圧力が大きく計測された。 しかし, 衝突点から離れたセンサ 3 においては, 無磁場下 より圧力波が強く減衰した. これより, 磁場下での圧力波 減衰は圧縮率のみに依存せず, 磁場による MR 流体の内 部構造の変化や降伏せん断応力増加の影響を受けると考 えられる。

\section{5 結言}

本研究では, MR 効果による圧力波の減衰を把握するた め, 無磁場下および磁場下で異なる粒子濃度の MR 流体 に対して飛翔体高速衝突実験および粘度測定を行った。 これらの実験から, MR 流体の粒子濃度や磁場下における 流動特性変化が衝突誘起圧力波の減衰に与える影響を調 查した。得られた知見を以下に示す.

(1) 衝突点付近でのピーク圧力は圧縮率に依存する.

（2）各 MR 流体中を伝ぱする衝突誘起圧力波は，センサ 3 において正規化したピーク圧力への伝ぱ距離による 圧力波減衰が磁場下の方が無磁場下より大きくなっ た。これは，磁場により MR 流体の内部構造が変化 し, 粘度やせん断応力, 音速などの物性值が変化する ためである。

（3）磁場による降伏せん断応力およびせん断応力上昇は 粒子濃度に依存する。

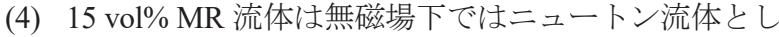
て，磁場下ではビンガム流体としての可逆的な特性 を併せ持つが，30 vol\% MR 流体は無磁場下でもビン ガム流体の特性を持つ.このことから, 粒子濃度が上 昇すると，粒子が流動抵抗となり無磁場下でもビン ガム流体として振る舞うことが確認された.

（5）磁場下の MR 流体の粘度はせん断速度の上昇に伴い 減少するが，無磁場下の粘度より值が小さくならな いことが確認された。粒子による流動抵抗だけでな く，磁場によって形成されたクラスタが流動抵抗と なっているためと考えられる。

本研究は，公益財団法人京都技術科学センターによる 研究開発費の助成を受けたものである.

\section{参 考 文 献}

1) G. Bossis, O. Volkova, S. Lacis and A. Meunier, "Magnetorheology: Fluids, Structures and rheology", Ferrofluids, Springer, Heidelberg, pp.202-230 (2002).

2) B. K. Kumbhar and S. R. Patil, "A study on properties and selection criteria for magnetorheological (MR) fluid components", International Journal of ChemTech Research, Vol.6, No.6, pp.3303-3306 (2014). 
3) F. D. Goncalves and J. D. Carlson, "Investigating the time dependence of the MR effect" International Journal of Modern Physics B, Vol.21, pp.4832-4840 (2007).

4) M. Ashtiani, S. H. Hashemabadi and A. Ghaffari, "A review on the magnetorheological fluid preparation and stabilization", Journal of Magnetism and Magnetic Materials, Vol.374, pp.716-730 (2015).

5) V. Sedlák and M. Kuffová, "Improving military vehicles performance with MR fluid technology”, Proceedings of the International Scientific Conference Modern Safety Technologies in Transportation, pp.161-165 (2015).

6) T. Fengchen, Q. Yang, C. He and L. Wang, "Experimental study and design on automobile suspension made of magneto-rheological damper" Energy Procedia, Vol.16, pp.417-425 (2012).

7) R. Ahamed, M. M. Ferdaus and Y. Li, "Advancement in energy harvesting magneto-rheological fluid damper: A review", Korea-Australia Rheology Journal, Vol.28, pp.355-379 (2016).

8) A. S. Shafer and M. R. Kermani, "Design and validation of a Magneto-Rheological clutch for practical control applications in human-friendly manipulation", Proceedings of 2011 IEEE International Conference on Robotics and Automation, pp.4266-4271 (2011).

9) S. R. Kang, S. W. Cha, Y. H. Hwang, Y. S. Lee and S. B. Choi, "Controllable magnetorheological fluid based actuators for 6-degree-of-freedom haptic master applicable to robot-assisted surgery", Sensors and Actuators A, Vol.279, pp.649-662 (2018).

10) F. D. Goncalves, "Characterizing the behavior of magnetorheological fluids at high velocities and high shear rates", Virginia Polytechnic Institute and State University Physics D Thesis (2005).
11) M. I. Varela-Jiménez, J. L. Vargas Luna, J. A. CortésRamiréz and G. Song, "Constitutive model for shear yield stress of magnetorheological fluid based on the concept of state transition", Smart Materials and Structures, Vol.24, pp.1-7 (2015).

12) Y. Nahmad-Molinari, C.A. Arancibia-Bulnes and J.C. Ruiz-Suárez, "Sound in a magnetorheological slurry" Physical Review Letters, Vol.82, pp.727-730 (1999).

13) X. Chen, X. Zhu, Z. Xu, Y. Lin and G. He, "An inductancebased technique for the measurement of magnetic moment of the magnetorheological fluids", Measurement, Vol.47, pp.693-697 (2014).

14) M. Motozawa, Y. Iizuka and T. Sawada, "Experimental measurements of ultrasonic propagation velocity and attenuation in a magnetic fluid", Journal of Physics Condensed Matter, Vol.20, pp.204117-204121 (2008).

15) T. Sawada, H. Nishiyama and T. Tabata, "Influence of a magnetic field on ultrasound propagation in a magnetic fluid”, Journal of Magnetism and Magnetic Materials, Vol.252, pp.186-188 (2002).

16) M. A. Bramantya, M. Motozawa and T. Sawada, "Ultrasonic propagation velocity in magnetic and magnetorheological fluids due to an external magnetic field", Journal of Physics Condensed Matter, Vol.22, pp.324102-324106 (2010).

17) S. A. Mazlan, N. B. Ekreem and A. G. Olabi, "An investigation of the behaviour of magnetorheological fluids in compression mode", Journal of Materials Processing Technology, Vol.201, pp.780-785 (2008).

18) C. Sarkar and H. Hirani, "Effect of particle size on shear stress of magnetorheological fluids", Smart Science, Vol.3, No.2, pp.65-73 (2015).

19) W. Huang, W. Zhang, P. Ren, Z. T. Guo, N. Ye, D. C. Li and Y. B. Gao, "An experimental investigation of waterfilled tank subjected to horizontal high speed impact", Experimental Mechanics, Vol.55, pp.1123-1138 (2015). 